\title{
ETIK-INTERNATIONAL SZANGHAJ. ZAMIERZENIE BADAWCZE I RAPORT Z KONSTRUOWANIA ZADAŃ TESTOWYCH DOSTOSOWANYCH DO KONTEKSTU CHIŃSKIEGO ${ }^{1}$
}

Streszczenie: W Szanghaju powstał zespół naukowców, którzy podjęli się przygotowania i przeprowadzenia w Chinach badania ETiK-International. W tym artykule opisano genezę powstania zespołu i jego dotychczasowe działania w celu przygotowania realizacji zamierzenia badawczego. Obszernie opisano pracę nad modyfikacją zadań testowych i dostosowaniem ich do chińskiego kontekstu społeczno-kulturowego.

Słowa kluczowe: badanie ETiK-International, zadanie testowe, kompetencja moralno-etyczna, uniwersalizm powtarzania.

W Chińskiej Republice Ludowej (ChRL) ideologia marksistowska odgrywa znaczącą rolę w życiu politycznym i społecznym. Moralność należy w niej do obszarów podlegających bezpośredniemu kształtowaniu przez państwo, zgodnie z ideałami komunizmu i tradycji kulturowej Chin. Wielowymiarowe zmiany cywilizacyjne prowadzą jednak współcześnie do tego, że proces szkolnego wychowania moralnego i nauczania moralno-etycznego staje przed nowymi wyzwaniami i wymaga wnikliwej refleksji pedagogicznej.

Pomysł przeniesienia na grunt chiński zamierzania badawczego ETiKInternational sięga swoimi korzeniami ponad 20-letniej współpracy Dietricha Bennera, którego w 2004 roku mianowano honorowym profesorem East China

${ }^{1}$ [Tekst został opublikowany w języku niemieckim pt. ETiK-International-Shanghai: Ansatz des Projekts und Bericht über die Konstruktion neuer, auf den chinesischen Kontext zugeschnittener Aufgaben w: Benner, Nikolova 2016, s. 254-272. Tytuły publikacji chińskich przywoływanych w tym artykule są podawane w polskiej wersji językowej. Pochodzące od tłumacza uzupełnienia i dopowiedzenia umieszczono w nawiasach kwadratowych i opatrzono dopiskiem „dop. D.S.”]. 
Normal University (ECNU) w Szanghaju, z naukowcami z tej uczelni. W związku ze współpracą D. Benner przebywał wielokrotnie w ECNU, prowadząc tam wykłady z pedagogiki ogólnej. W przekładzie na język chiński ukazały się one dokładnie 10 lat temu (Benner 2006). Problematyka tych wykładów w ostatniej dekadzie uległa jednak modyfikacji. Wynikało to $\mathrm{z}$ faktu, że profesor realizował w Berlinie projekt ETiK. W nawiązaniu do projektu powstało opracowanie, w którym $z$ historyczno-teoretycznego punktu widzenia wspólnie przeanalizowaliśmy ideę nauczania moralno-etycznego (Benner i in. 2015). To z kolei skłoniło nas do samodzielnego już prześledzenia reform wychowania moralnego i nauczania moralno-etycznego w minionych trzech dekadach w ChRL (Peng, Peng 2016). Te działania przygotowały grunt pod zainicjowanie w ECNU międzynarodowego badania ETiK-International, o którym tutaj będzie mowa.

Niniejszy tekst składa się z czterech części. W pierwszej zrekapitulowano drogę, która doprowadziła do powstania chińskiego zespołu ETiK-International. Druga część zawiera opis zmian wprowadzonych w berlińskim Teście Kompetencji Moralno-Etycznej Piętnastolatków (TKM-EP) w związku z pierwszym badaniem pilotażowym, które odbyło się w Szanghaju wiosną 2015 roku. W trzeciej części podano ogólną charakterystykę czynności związanych z konstruowaniem nowych zadań do chińskiej wersji TKM-EP. W następnej, czwartej części, omówiono w szczegółach wybrane pytania testowe i wyjaśniono sposób ich interpretowania.

\section{Geneza badania ETiK-International w Szanghaju}

Powołany jesienią 2014 roku do istnienia zespół ETiK-International w Szanghaju jest pierwszym, jaki powstał do tej pory poza obszarem Europy. Jego praca rozpoczęła się w ważnym momencie historycznym, który wyznaczają coraz wyraźniejsze oznaki zmiany dokonującej się w chińskim organizmie państwowym, do tej pory zdecydowanie preferującym kolektywne wychowanie państwowe nakierowane na kształtowanie w młodym pokoleniu światopoglądu komunistycznego i odpowiednich cnót obywatelskich. Zasygnalizowana zmiana oznacza w sferze edukacji odejście od protekcjonalizmu i normatywizmu partyjnego i położenie większego nacisku na kształtowanie w uczniach samodzielności myślenia i oceniania.

Na powyższym tle nowego znaczenia nabierają takie pytania, jak: jaki jest stan rozwoju kompetencji sądzenia moralno-etycznego i kompetencji projektowania działania w tym samym zakresie u chińskich uczniów i uczennic?, czy i jeżeli tak, to jaka różnica zachodzi między chińskimi uczniami a ich rówieśnikami z Niemiec i innych krajów Europy w zakresie podstawowej wiedzy moralno-etycznej, kompetencji sądzenia moralno-etycznego i kompetencji projektowania działania moralno-etycznego?; czy wypracowane w berlińskim projekcie ETiK i potwierdzone empirycznie poziomy oczekiwań odnośnie do wymienionych właśnie trzech kompetencji cząstkowych mogą służyć również do scharakteryzowania kompetencji moralno-etycznej uczniów i uczennic z ChRL, czy też dadzą się wyodrębnić inne 
jeszcze poziomy?; czy istnieją i jeżeli tak, to na czym polegają fenomeny kulturowe wyróżniające chińskie myślenie i działanie moralno-etyczne?; czy w związku z tym można stosować TKM-EP w innym kontekście kulturowo-cywilizacyjnym, wiedząc, że został on opracowany w Niemczech i wypróbowany w warunkach kultury europejskiej?; które zadania z tego testu można zastosować w Chinach, a które nie i dlaczego?; czy da się skonstruować pytania testowe dostosowane do swoistości kultury i mentalności chińskiej i jak rozwiążą je uczniowie z Niemiec?; jakie poziomy osiągną uczniowie i uczennice z Chin w poszczególnych zakresach kompetencji moralno-etycznej, rozwiązując zadania „europejskie”, a jakie osiągną w zadaniach „chińskich”?; czy w tradycyjnie chińskich koncepcjach sądzenia i działania moralnego mogą powstać nowe przestrzenie, które szkolna edukacja moralno-etyczna wykorzysta do konstruowania takich programów nauczania etyki, które nie będą kolonizować i europeizować chińskiej moralności (uniwersalizm powtarzania), lecz raczej będą wspierać rozwój autonomicznej kompetencji moralno-etycznej?

Powyższe pytania to tylko niektóre $\mathrm{z}$ długiej listy, jaka powstała w związku z rozpoczęciem pracy przez zespół ETiK-International w Szanghaju. Z pewnością postępy w realizacji podjętego zamierzenia badawczego sprawią, że wkrótce zrodzą się następne pytania.

Jak wskazano we wstępie, ważnym czynnikiem motywującym do zwrócenia uwagi na wychowanie respective nauczanie moralno-etyczne w Chinach były wieloletnie wykłady prowadzone przez D. Bennera w ECNU. Podczas jednego z ostatnich pobytów profesora w Sznghaju, tj. jesienią 2013 roku, tematem wiodącym był związek między doświadczeniem, nauczaniem, uczeniem się, wiedzą a lekcjami szkolnymi. Dla zilustrowania tej złożonej i jednocześnie fundamentalnej dla kształcenia szkolnego problematyki honorowy profesor ECNU często sięgał po przykłady z berlińskiego TKM-EP. Jak należało się spodziewać, te dopełnienia wzbudziły wśród chińskich studentów duże zainteresowanie, a zwłaszcza rozważania sytuacji moralnych. Być może było to spowodowane tym, że wielu z nich wskutek wspomnianego powyżej kryzysu ideologii państwowej znajdowało się $\mathrm{w}$ procesie teoretyczno-kognitywnej i moralno-etycznej transformacji. Nie bez znaczenia miała również odczuwana współcześnie wśród młodych Chińczyków otwartość na idee pluralizmu i demokracji.

Po powyższych wykładach Tao Peng, który tłumaczył na język chiński dociekania D. Bennera, wyraził chęć bliższego zapoznania się z projektem ETiK w Berlinie i gotowość zaszczepienia go w ChRL jako badania ETiK-International. Realizacja tego pragnienia wiązała się z koniecznością jego przybycia na Uniwersytet Humboldtów do Berlina i podjęcia studiów doktoranckich. Uzyskane w Chinach czteroletnie rządowe stypendium naukowe otwarło mu drogę do urzeczywistnienia tych planów.

Rozpoczęcie przez T. Penga studiów doktoranckich na Uniwersytecie Humboldtów, pod okiem D. Bennera, stanowi pierwszy, ale nie jedyny krok w stronę realizacji badania ETiK-International w Szanghaju. Kolejnym krokiem 
było włączenie go w pracę berlińskiego zespołu ETiK, który w tym okresie (koniec roku 2013) finalizował badanie terenowe w Berlinie i Brandenburgii. Jednak pomyślna realizacja bania ETiK-International w Szanghaju zależała od pozyskania środków na przygotowanie zeszytów testowych, przeprowadzenia badań pilotażowych i badania zasadniczego oraz ewaluacji wyników. Dzięki działaniom podjętym przez D. Bennera udało się pozyskać wsparcie finansowe instytucji, o których będzie teraz mowa.

Władze ECNU zadeklarowały pokrycie kosztów przyjazdu i pobytu niemieckich naukowców, którzy będą nadzorować przebieg badania pilotażowego w Szanghaju. Fundacja „Fritz Thyssen Stiftung” wzięła na siebie sfinansowanie przygotowania, przebiegu i opracowania statystycznego danych zgromadzonych podczas badania zasadniczego. Natomiast fundacja „Alexander von Humboldt-Stiftung” zobowiązała się do pokrycia kosztów współpracy instytucjonalnej między kierowaną przez Zhengmei Penga w ECNU Katedrą Teorii Kształcenia i Katedrą Ogólnych Podstaw Nauki o Wychowaniu na Uniwersytecie Humboldtów, którą reprezentuje były jej kierownik - D. Benner. Z tego funduszu zostaną również sfinansowane wizyty studyjne szanghajskiego zespołu ETiK-International w Berlinie i vice versa - berlińskiego zespołu ETiK w Szanghaju, a ponadto konferencja naukowa zorganizowana na zakończenie badania, podczas której zostaną przedstawione i omówione wyniki projektu. Jak już wspomniano powyżej, stypendium naukowe T. Penga jest finansowane ze środków budżetowych ChRL.

Po uregulowaniu kwestii finansowanych, jesienią 2014 roku zespół ETiKInternational Szanghaj rozpoczął praktyczną pracę. Najpierw zostały przełożone na język chiński wszystkie zadania zawarte w berlińskim TKM-EP. Już przy tłumaczniu starano się dostosować je do specyfiki kontekstu chińskiego. Poza tym okazało się, że nie wszystkie zadania mogą zostać użyte. Po wyselekcjonowaniu puli złożonej z 68 pytań zorganizowano w maju 2015 roku w wybranych szanghajskich szkołach średnich pierwsze badanie pilotażowe. Równolegle T. Peng przeprowadził wywiady z pięcioma chińskimi nauczycielkami i nauczycielami, którzy prowadzą przedmiot pod nazwą „Myślenie i cnota”, odpowiadający europejskich lekcjom etyki.

Od czerwca do września 2015 roku berlińska część zespołu ETiK-International Szanghaj pracowała nad skonstruowaniem 15 nowych zadań testowych, które współgrają z obowiązującym w Szanghaju programem nauczania (Program nauczania... 2004) i wymaganiami programowymi (Wymagania programowe..., 2010) dla dwóch przedmiotów: „Myślenie i cnota” i „Myślenie i polityka”, podczas których realizowane są treści moralno-etyczne. Drugie badanie pilotażowe odbyło się pod koniec listopada 2015 roku. Ponieważ do tej pory nie zakończono socjometrycznej analizy danych uzyskanych w obu badaniach, poniższy raport odnosi się wyłącznie do prac podjętych podczas przygotowania pierwszego badania pilotażowego. 


\section{Raport z przygotowań do pierwszego badania pilotażowego}

Celem zamierzenia badawczego ETiK-International jest sprawdzenie wartości psychometrycznej Testu Kompetencji Moralno-Etycznej Piętnastolatków (TKM-EP), który opracowano w trakcie realizacji projektu ETiK w Berlinie i który pomyślnie przeszedł proces walidacji w Niemczech. W odniesieniu do Szanghaju chodzi dodatkowo o ocenę trafności i rzetelności tego narzędzia w warunkach kulturowych całkowicie odmiennych od tych, w których projekt powstał.

Podobnie jak to miało miejsce w berlińskim projekcie ETiK i zrealizowanych do tej pory badaniach ETiK-International w Warszawie i Wiedniu, grupą, do której kieruje się badanie, są uczniowie szkół publicznych uczestniczący w szkole w zajęciach odpowiadających europejskim lekcjom etyki. Już przy wstępnym rozważaniu możliwości badania edukacji moralno-etycznej w Chinach, jesienią 2013 roku oczywistością było, że nie może chodzić o prostą aplikację TKM-EP. Również adaptacja powinna mieć charakter daleko idącej modyfikacji zadań testowych. Pytanie tylko - adaptacji idącej jak daleko? Znalezienie odpowiedzi na to pytanie było jednym z głównych zadań po ukonstytuowaniu się zespołu ETiKInternational w Szanghaju.

Przy poszukiwaniu rozstrzygnięcie dla postawionej powyżej kwestii dużą pomocą okazało się porównanie chińskich planów nauczania z niemieckimi, na których opierała się konstrukcja TKM-EP. Przeprowadzona analiza komparatystyczna wykazała, że w niemieckim oryginale nie uwzględniono wystarczająco wyraźnie trzech zakresów tematycznych, istotnych z chińskiego punktu widzenia. Ponadto dla jednego zakresu tematycznego trzeba było przygotować nowe pytania-zadania, które będą pasować do sytuacji prawnej w Chinach. Chodziło konkretnie o zadania dotyczące przestępstwa określanego w europejskim systemie prawnym jako umyślne nieudzielenie pomocy.

Do wspomnianych trzech zakresów, które w niemieckiej wersji TKM-EP całkowicie pominięto lub potraktowano zbyt lakonicznie, należał patriotyzm. Natomiast w Chinach przywiązuje się do niego szczególnie duże znaczenie. Drugi zakres wyznaczały problemy moralno-etyczne powstające między jednostką a kolektywem i vice versa. Zgodnie z obowiązującymi w ChRL normami etycznymi zbiorowości (kolektywowi) przysługuje bezwzględne pierwszeństwo przez interesami jednostki. Na trzeci zakres składały się relacje rodzinne, a w szczególności te między rodzicami i dziećmi. W programie nauczania do wspomnianego już przedmiotu „Myślenie i cnota” problematyce rodzinnej poświęca się wyjątkowo dużo miejsca (Program nauczania..., 2004, s. 45-47). W przeciwieństwie do tego w obowiązującym w Berlinie programie nauczania etyki i w skorelowanych z nim podręcznikach dla klas 7-8 i 9-10 kwestii życia w rodzinie nie porusza się w ogóle (Brüning 2006; 2008). Gdyby próbować wyjaśnić tę dysproporcję, z pewnością należałoby wskazać na fakt, że w Niemczech wychowania rodzinnego nie definiuje się ani nie legitymizuje się przez odwołanie do teorii państwa, a to ostatnie w Chinach ma prawo 
ingerować bezpośrednio w sprawy wychowania rodzinnego. W Europie coś podobnego jest możliwe tylko wówczas, gdy rodzice w poważnym stopniu zaniedbują swoje obowiązki rodzicielskie lub/i nadużywają wobec dzieci posiadanej władzy.

Ze wskazanych powyżej rozbieżności wyniknęła podwójna potrzeba modyfikacji TKM-EP. Po pierwsze, należało przekształcić część zadań testowych przez rozbudowanie kafeterii odpowiedzi tak, żeby uwzględniały one specyficzny kontekst chiński. Po drugie, trzeba było skonstruować całkowicie nowe zadania, których nie uwzględniały ani niemieckie programy nauczania etyki, ani finansowany przez Deutsche Forschungsgemeinschaft (DFG) berliński projekt ETiK. Te nowe pytania-zadania werbalizowały wiedzę i sądy moralne dotyczące patriotyzmu, odpowiedzialności kolektywnej i indywidualnej, podporządkowania dzieci wobec rodziców, solidarnej pomocy w trudnych sytuacjach życiowych oraz napięć między legalnością a moralnością.

W związku z konstruowaniem nowych zadań do chińskiej wersji TKM-EP bardzo pomocne okazało się to, że w Szanghaju oprócz szczegółowego programu nauczania wspomnianego przedmiotu był do dyspozycji również zeszyt ćwiczeń zawierający zadania, które służyły nauczycielom do kontrolowania, czy w trakcie lekcji osiągnięto założone cele edukacyjne. Wychodząc od tego właśnie zeszytu ćwiczeń, przystąpiono do opracowywania nowych pytań testowych. Należy podkreślić, że te nowe pytania nie były kopią zadań z zeszytu ćwiczeń. Naszym celem było wykoncypowanie takich sytuacji problemowych, w których chińscy uczniowie będę niejako zmuszeni do przeprowadzenia refleksji i udzielenia odpowiedzi z wykorzystaniem dostępnej im podstawowej wiedzy moralno-etycznej (PWM-E), kompetencji sądzenia moralno-etycznego (KSM-E) i kompetencji projektowania działania o tym samym charakterze (KPDM-E). Tylko pod tym warunkiem możliwe będzie porównanie wyników uzyskanych w Szanghaju z tymi, które osiągnęli uczniowie uczestniczący w projekcie ETiK i w międzynarodowym badaniu ETiK-International.

\section{Od ćwiczeń sprawdzających efekty nauczania szkolnego do zadań TKM-EP}

Ze wspomnianych w poprzedniej części zeszytów ćwiczeń najpierw wyselekcjonowano 24 zadania na temat patriotyzmu, kolektywu i życia rodzinnego. Ponieważ jednak niektóre z nich wykazywały wyraźne zabarwienie ideologiczne i nie dawały się przyporządkować do żadnego z trzech zakresów kompetencji moralno-etycznej, zrezygnowano z ich dalszego optymalizowania. Odnośnie do odrzuconych zadań głównym kryterium eliminacji był ich tautologiczny charakter. Ten charakter przejawiał się przede wszystkim w tym, że już sam sposób stawiania pytania sugerował właściwą respective oczekiwaną odpowiedź. Przez to niemożliwe było zastosowanie ich w celu empirycznego sprawdzenia zakresów i poziomów kompetencji moralno-etycznej.

Tak więc z początkowej puli 24 zadań zaakceptowano 15, które poddano dalszemu przepracowaniu. Ostatecznie satysfakcjonujący poziom, umożliwiający 
włączenie tych zadań do zakresu PWM-E, osiągnęło jedno zadanie, siedem zostało włączonych do KSM-E i również siedem do KPDM-E.

Przekształcając zadania z zeszytów ćwiczeń na zadania do TKM-EP, kierowaliśmy się wskazówkami zawartymi w tychże zeszytach odnośnie do prawidłowych i nieprawidłowych odpowiedzi. Następnie nasza praca polegała na rozszerzeniu kafeterii odpowiedzi o dalsze warianty do zakreślenia. Jeżeli rzecz tego wymagała, przekształcaliśmy pierwotne sformułowanie tak, żeby bardziej wyeksponować interesującą nas sytuację problemową. Ważne było przy tym uniknięcie pytań światopoglądowych czy też odwołujących się do utartych obyczajów i norm. Naszym celem było opracowanie zadań testowym, w których zostaną zwerbalizowane wymienione powyżej kompetencje cząstkowe i ich poziomy oczekiwań.

Opisane do tej pory zabiegi w celu przekształcenia i dostosowania TKM-EP do specyfiki ChRL ożywiała nadzieja na to, że za pomocą nowoskonstruowanych zadań uda się ustalić, czy i jeżeli tak, to na ile chińscy uczniowie są w stanie rozpoznać oczekiwania ukryte w planach nauczania przedmiotów „Myślenie i cnota” oraz „Myślenie i polityka”. Wyrazem tych oczekiwań były prawidłowe i nieprawidłowe odpowiedzi na zadania z zeszytów ćwiczeń. Ponadto interesowało nas, czy przy rozwiązywaniu TKM-EP będą oni zdolni do wykorzystania przestrzeni wolności otwierających się dzięki myśleniu refleksyjnemu i do sformułowania samodzielnej odpowiedzi na przedstawioną w zadaniu testowym sytuację problemową respective dylemat moralny. Warunkiem możliwości tego ostatniego jest posiadanie ukształtowanej kompetencji moralno-etycznej, której empiryczne ujęcie postawiliśmy sobie za cel badania.

Wprowadzenie we wspomniane powyżej przestrzenie wolności dokonywało się przez to, że rozwiązując TKM-EP, uczniowie nie mieli do zakreślenia tylko jednej (prawidłowej) odpowiedzi. W każdej kafeterii było wiele odpowiedzi prawidłowych, a jednocześnie żadna $z$ nich nie była jedyną prawidłową. Chcieliśmy bowiem zmusić ich do skonstruowania własnego rozwiązania. $Z$ tego powodu zadania testowe zostały przygotowane przez nas tak, żeby żadna $\mathrm{z}$ proponowanych odpowiedzi nie dawała pełnego rozwiązania. Przez wielokrotne zaznaczenia uczniowie mogli zestawiać ze sobą różne prawidłowe odpowiedzi, szukając takiego połączenia, które najlepiej odzwierciedli ich własny punkt widzenia.

W przypadku niestandaryzowanych otwartych pytań posłużyliśmy się formą udzielania odpowiedzi, która umożliwiła respondentom wykorzystanie zarówno odpowiedzi odwołujących się do tradycji chińskiej, jak i takich, w których wyraźnie zaznacza się wpływ kultury europejskiej. Oprócz tego daliśmy im możliwość pójścia trzecią drogą, poszukiwania rozwiązania zgodnego z własnym punktem widzenia.

W świetle zrekonstruowanego do tej pory procesu przygotowywania chińskiej wersji TKM-EP można powiedzieć, że celami przeprowadzonej transformacji było podniesienie poziomu złożoności zadań zaczerpniętych z szanghajskich zeszytów ćwiczeń, które nie tylko nie wykazywały się dostateczną subtelnością, lecz bez tej transformacji nie mogłyby również służyć do ujmowania różnorodnych aspektów 
sądzenia moralno-etycznego i projektowania działania w tym zakresie. Zadania w owych zeszytach ćwiczeń były bowiem zawężone do wąsko określonych treści odnoszących się do konkretnych rozdziałów podręcznika. Przez ich przeformułowanie uzyskaliśmy pytania-zadania, za pomocą których można było „zderzyć” chińskich uczniów i uczennice ze złożonymi sytuacjami moralno-etycznymi i poprosić ich o zajęcie własnego stanowiska wobec przedstawionych problemów.

Drugą zaletą nowych zadań testowych były relatywnie proste i ukierunkowane na pożądane odpowiedzi pytania, które zostały niejako wbudowane w różnorodne opcje stwarzające możliwość dokonywania wielostronnej i zniuansowanej analizy problemów poddanych do rozwiązania. To z kolei zmusiło respondentów do odwoływania się przy przeprowadzaniu refleksji moralnej do różnych form sądzenia moralno-etycznego. Żeby dowiedzieć się, czy uczniowie rzeczywiści dokonują złożonych analiz, przygotowaliśmy dwojakiego rodzaju wskaźniki. W zadaniach testowych na zaznaczenie mierzyliśmy je za pomocą szerokiej gamy odpowiedzi do wyboru. Przy otwartych pytaniach przyjęto jako wskaźnik to, czy i w jaki sposób młodzi ludzie uzasadniają swoje decyzje, a w szczególności, czy uwzględniają inne perspektywy widzenia danego problemu, czy tylko swoją perspektywę. Odnośnie do tego ostatniego pomocne okazały się wyodrębnione w berlińskim projekcie ETiK płaszczyzny argumentowania: prawna, ekonomiczna, polityczna i moralno-etyczna.

Trzecim efektem dokonanej transformacji zadań z szanghajskich zeszytów ćwiczeń było zaproponowanie uczniom możliwości poszukiwania rozwiązań w oparciu o posiadaną przez nich, przynajmniej zalążkowo, władzę sądzenia moralno-etycznego i dyskursywną zdolność projektowania działania w tym zakresie w miejsce silnie eksponowanej w zeszytach postawy wierności aktualnemu chińskiemu systemowi politycznemu i zawłaszczonej przez niego tradycji narodowej. Nieoczywistość takiego podejścia stanie się jeszcze bardziej wyraźna, gdy dodamy, że w chińskich szkołach głównym przesłaniem zajęć z przedmiotu „Myślenie i cnota” jest zaszczepienie określonej hierarchii wartości komunistycznych i „wyćwiczenie” uczniów w realizacji afirmatywnych form postępowania indywidualnego i zbiorowego. Przy modyfikacji zadań z zeszytów ćwiczeń nie chodziło nam bynajmniej o to, żeby typowe dla Chin sposoby sądzenia moralno-etycznego zastąpić (lepszymi?) europejskimi respective niemieckimi, lecz o to, żeby sytuacje problemowe wywodzące się z chińskiego kontekstu kulturowego dostosować do kategorii wypracowanych w projekcie ETiK, a mianowicie trzech kompetencji cząstkowych wraz z ich poziomami oczekiwań.

Odnośnie do problemu walidacji naszym celem było sprawdzenie, czy opracowane przez niemieckich pedagogów w Berlinie narzędzie badawcze spełni te same funkcje w odmiennej kulturze, tzn. czy uczestnicy badania będą rozwiązywać zadania testowe w sposób umożliwiający, z jednej strony, uchwycenie elementów wspólnych, z drugiej natomiast specyficznych i właściwych tylko dla Chin. W tym kontekście bardzo przydatne okazało się wprowadzone przez Michaela 
Walzera rozróżnienia między „uniwersalizmem globalnie obowiązującego prawa” (Universalismus des einen weltweit geltenden Gesetzes) a „uniwersalizmem powtarzania" (Universalismus der Wiederholung). Autor przedstawił je w wydanej w połowie lat 90. minionego wieku książce Thick and Thin. Moral Argument at Home and Abroad (Walzer $1996^{2}$ ). Drugi $\mathrm{z}$ wyróżnionych rodzajów uniwersalizmu oznacza, w odniesieniu do moralności, takie myślenie, sądzenie i projektowanie działania w tym obszarze, które nie jest z góry zdeterminowane, jak to ma miejsce przykładowo w sylogizmach logicznych, lecz cechuje się wieloaspektowością, refleksyjnością i podejściem problemowym. Z pedagogicznego punktu widzenia te właśnie znamiona uniwersalizmu powtarzania wydają się szczególnie przydatne do uczenia moralności (Benner i in. 2015, s. 183-202).

\section{Przykłady zadań testowych z wybranych obszarów tematycznych}

Jak wyjaśniono powyżej, adaptacja berlińskiego TKM-EP polegała przede wszystkim na przygotowaniu nowych zadań testowych do pominiętych całkowicie lub w niedostateczny sposób wyeksponowanych w projekcie obszarów tematycznych. Te obszary opatrzono następującymi nazwami: „Patriotyzm”, „Jednostka a kolektyw”, „Życie w rodzinie” i „Pomoc wzajemna - między legalnością i moralnością”. W tej części artykułu na wybranych przykładach zostanie przedstawiony proces przygotowywania zadań testowych. Prezentacja będzie przebiegać w trzech etapach. Najpierw zostanie zacytowane i skomentowane pierwotne zadanie z zeszytu ćwiczeń, następnie wyjaśnimy problem, z powodu którego zadanie zostało poddane modyfikacji. W trzecim etapie zaprezentujemy nową wersję tego zadania, jaka została zastosowana w badaniu pilotażowym w maju 2015 roku.

\section{Obszar tematyczny „Patriotyzm”}

Z zeszytu z zadaniami do przedmiotu „Myślenie i cnota” wybrano następujące zadanie (Zeszyt ćwiczeń 2010, s. 122):

Yao Ming, słynny chiński koszykarz, był w 2008 roku w Pekinie reprezentantem ChRL. Wziął również udział w ceremonii otwarcia paraolimpiady i z tego powodu nie mógł uczestniczyć w konferencji prasowej zorganizowanej przez jego klub Houston Rockets w USA. Za złamanie postanowień umowy zarząd klubu nałożył na sportowca wysoką karę pieniężną. Yao Ming jest

${ }^{2}$ [Autorzy tekstu odwołują się do niemieckiego tłumaczenia książki M. Walzera. Niestety polski przekład różni się od niemieckiego. Znajduje się w nim tylko pięć pierwszych rodziałów książki M. Walzera, które tworzą w publikacji niemieckiej jedną część. Natomiast drugiej części, która jest bardzo ważna dla tego punktu rozważań, brakuje całkowicie w polskiej edycji - dop. D.S.] 
jednak zdania, że opłaca się zapłacić tę karę w zamian za udział w otwarciu paraolimpiady.

Postępowanie Yao Minga świadczy o tym, że:

A. Interesom państwa należy się zawsze pierwszeństwo.

B. Interesy prywatne muszą niekiedy ustąpić pierwszeństwa interesom państwa.

C. Obywatele powinni czynnie wpierać interesy państwa.

Powyższe zadanie znajduje się we wspomnianym Zeszycie ćwiczeń na końcu cyklu lekcji pod tytułem: „Wysiłek na rzecz rozwoju narodu chińskiego i wspólna odpowiedzialność". W cyklu tym uczniowie dowiadują się, że u podstaw sukcesu osobistego leży zawsze dobro państwowe. Stąd każdemu obywatelowi zlecona jest w pierwszym rzędzie troska o zagwarantowanie realizacji interesów państwa i zachowanie właściwej harmonii w tym zakresie.

Patrząc z perspektywy chińskiego patriotyzmu, wszystkie proponowane odpowiedzi - A, B i C - są prawidłowe. A zatem to zadanie nie ma jednej prawidłowej odpowiedzi, którą uczniowie mogliby wskazać ani nie jest zadaniem typu multiple choice. Trzeba w nim zakreślić wszystkie odpowiedzi. Jednak przez taki sposób postępowania zawęża się właściwie problem, którego dotyczy zadanie. Ten problem to kwestia oceny różnicy między prywatnymi interesami jednostki a interesem państwa. Najwidoczniej od uczniów oczekuje się jedynie afirmacji ideologicznie określonego prymatu wartości państwowych ponad wartościami osobistymi.

Gdyby na powyższe zadanie spojrzeć z psychometrycznego punktu widzenia, to należałoby stwierdzić, że nie ma ono żadnej wartości diagnostycznej. Podobna ocena musi zostać postawiona, gdy spojrzy się na to zadanie z perspektywy moralno-etycznej lub nawet politycznej, nie mówiąc już o dydaktyczno-pedagogicznej. Uczniowie i uczennice muszą nauczyć się tego, co według przyjętego klucza ustalono, że mają umieć.

Po uwzględnieniu powyższej krytyki zadanie przekształcono w następujący sposób:

Yao Ming, słynny chiński koszykarz, był w 2008 roku w Pekinie reprezentantem ChRL. Wziął również udział w ceremonii otwarcia paraolimpiady i z tego powodu nie mógł uczestniczyć w konferencji prasowej zorganizowanej przez jego klub Houston Rockets w USA. Za złamanie postanowień umowy zarząd klubu nałożył na sportowca wysoką karę pieniężną.

Przedstawioną sytuację i wynikające z niej konsekwencje można rozpatrywać $\mathrm{z}$ różnych punktów widzenia.

Która z podanych poniżej propozycji odpowiedzi jest Twoim zdaniem najwłaściwsza z moralnego punktu widzenia? Zakreśl ją.

Uwaga! Tylko jedna odpowiedź jest prawidłowa. 
A. Interesom państwa należy okazać zawsze pierwszeństwo przed osobistymi interesami zawodowymi, dlatego Yao Ming powinien opuścić Houston Rockets, jeżeli zarząd tego klubu nie szanuje jego obowiązków jako obywatela Chin.

B. Osobiste interesy zawodowe nie muszą kolidować z obowiązkami obywatelskimi, dlatego Yao Ming powinien zapłacić nałożoną na niego karę; przy jego dochodach, które sięgają wielu milionów dolarów, nie będzie to dla niego znaczącą stratą.

C. Obowiązki obywatelskie i zawodowe trzeba uzgadniać z obydwiema stronami, dlatego Yao Ming powinien zatroszczyć się o znalezienie takiego rozwiązania, które pomoże jego klubowi uznać jego zobowiązania wobec państwa chińskiego i Chinom wobec klubu, który go zatrudnia.

D. Prywatne umowy w sprawie pracy mają pierwszeństwo przed obowiązkami obywatelskimi, dlatego Yao Ming powinien zostać w Houston Rockets i rozpocząć starania o uzyskanie amerykańskiego obywatelstwa.

Uwagi do proponowanych odpowiedzi:

1) odpowiedź A jest całkowicie zgodna z ideologią chińskiego patriotyzmu. Została przejęta z Zeszytu ćwiczeń i zradykalizowana;

2) w odpowiedzi B ucieleśnia się myślenie pochodzące ze sfery ekonomicznej, w którym nie ceni się argumentacji odwołującej się do moralności;

3) odpowiedź C ilustruje tożsamość nowoczesnego człowieka, który należy równocześnie do różnych grup (kolektywów) i dlatego zmuszony jest do szukania takich regulacji, które umożliwią mu uzgodnienie sprzeczych ze sobą zobowiązań etyczno-moralno-prawnych;

4) w odpowiedzi C uwidocznia się tendencja do uprzywilejowywania jednostki i wąskiego kolektywu, do którego należy, np. umowa o pracę przeciwstawiona kolektywowi państwowemu.

Mamy nadzieję, że dzięki przeprowadzonej modyfikacji nowe zadanie umożliwi sprawdzenie, czy chińscy uczniowie bardziej preferują ugruntowaną w patriotycznej tradycji Chin odpowiedź A, czy uznają odpowiedź C za bardziej adekwatną do współczesności, czy może zaznaczą odpowiedź $\mathrm{B}$ respective $\mathrm{D}$, jako tę, która wyraża ich osobiste preferencje. Naszym głównym zamiarem było pobudzenie uczniów do refleksji nad przedstawionym problemem, zwrócenie ich uwagi na sprzeczne zobowiązania, które się w nim zawierają, i uzyskanie od nich wskazania, jak rozwiązać problemową sytuację.

\section{Obszar tematyczny „Jednostka a kolektyw”}

Tak jak powyżej, zadanie wybrano z Zeszytu ćwiczeń do przedmiotu „Myślenie i cnota”. Tym razem jest ono następujące (Zeszyt ćwiczeń 2010, s. 12): 
Kolektyw to społeczność, którą tworzą ludzie w określonym celu. Dzięki czemu jakaś społeczność osiąga status kolektywu?
A. Dzięki mądrości zbiorowej zespołu klasowego.
B. Dzięki przewodzeniu nauczyciela klasy.
C. Dzięki wysiłkowi wszystkich uczniów i uczennic.

W kluczu rozwiązań podano, że jedynie odpowiedź C jest prawidłowa. Tak więc klasa nie staje się kolektywem dzięki prowadzeniu przez nauczyciela ani dzięki zbiorowej mądrości zespołu klasowego, lecz wyłącznie dzięki wspólnemu wysiłkowi uczniów i uczennic, którzy ją tworzą. Przesłanie, które z tego można wyczytać, brzmi następująco: klasa powinna kierować się w myśleniu i działaniu wyłącznie własnym wglądem, a nie zdaniem tworzących ją pojedycznych osób czy nauczyciela.

Modyfikując powyższe zadanie, postawiono sobie za cel podniesienie jego poziomu złożoności przez uwypuklenie relacji między kolektywem klasowym a innymi kolektywami. Nowe zadanie powinno skłaniać rozwiązujących je uczniów nie tylko do rozróżnienie różnych rodzajów kolektywu, lecz również do dostrzeżenia i oceny relacji zachodzących między kolektywem a osobami, które go stanowią.

Przekształcone nowe zadanie brzmiało następująco:

Kto $\mathrm{z}$ moralnego punktu widzenia tworzy porządek kolektywu?

Zakreśl prawidłową odpowiedź.

Uwaga! Tylko jedna odpowiedź jest prawidłowa.

A. Wszyscy należący do kolektywu (np. klasy szkolnej, zakładu pracy, rodziny, związku sportowego, narodu) przez relizowanie powierzonych im zadań decydują o życiu wspólnym.

B. Członkowie jednego kolektywu (np. klasy szkolnej, zakładu pracy) mogą być równocześnie członkami innego (np. rodziny, związku sportowego) i dlatego muszą uzgadniać zadania, które zostały im powierzone przez te kolektywy.

C. Różne rodzaje kolektywów tworzą układ hiararchiczny. W tym układzie kolektyw państwowy ma pierwszeństwo przed kolektywami indywidualnymi, a te ostatnie przed prywatnymi.

D. Kolektywy tworzą naturalny, harmoniczny układ, który powstaje sam z siebie.

Uwagi do proponowanych odpowiedzi:

Współcześnie społeczeństwa o demokratycznej strukturze wewnętrznej dają możliwość tworzącym je jednostkom równoczesnej partycypacji w wielu różnych społecznościach czy wspólnotach, bez konieczności indentyfikowania się tylko z jedną z nich (Benner i in. 2015, s. 152 i n.). Podobna sytuacja panuje obecnie 
również w ChRL, gdzie dorastający muszą niejako koordynować swoje uczestnictwo w różnych kolektywach. W związku z tym można powiedzieć, że:

1) odpowiedź A reprezentuje skrajnie kolektywistyczny punkt widzenia, który dominował w Chinach w okresie dyktatury Mao Tse-tunga;

2) odpowiedź B jest prawidłowa $\mathrm{z}$ perspektywy nowoczesnego społeczeństwa chińskiego,

3) odpowiedź C jest prawidłowa w świetle szanghajskiego planu nauczania etyki,

4) w odpowiedzi D uwidocznia się idea nadmiernego harmonizowania różnic, która można dostrzec przykładowo w taoizmie, tradycyjnym chińskim systemie filozoficzno-religijnym.

Sprawą otwartą pozostaje, którą z powyższych odpowiedzi wybiorą uczniowie i uczennice uczestniczący w badaniu ETiK-International. Naszym zdaniem odsetek tych, którzy zakreślą odpowiedź B jako prawidłową, może być traktowany jako wskaźnik tego, na ile zmodernizowała się edukacja moralna w Chinach. Na marginesie należy zauważyć, że konieczne jest wyjaśnienie w dodatkowym badaniu zachowania uczniów przy zakreślaniu odpowiedzi.

\section{Obszar tematyczny „Życie w rodzinie”}

Z Zeszytu ćwiczeń do przedmiotu „Myślenie i cnota”, przeznaczonego na drugi semestr klasy 7, wyselekcjonowano następujące dwa zadania (Zeszyt ćwiczeń 2014, S. 2):

1. Każde dziecko ma swoje tajemnice. Rodzice niekiedy przeglądają listy czy pamiętniki swoich dzieci. W takich przypadkach dziecko powinno:

A. Upomnieć rodziców i zarządać od nich szacunku wobec swoich tajemnic.

B. Odpowiednio wcześniej porozmawiać z rodzicami.

C. Okazać zrozumienie dla troski rodziców.

2. Gdy między członkami rodziny rodzą się nieporozumienia, wówczas należy:

A. Wczuć się w sytuację i wzajemnie sobie przebaczyć.

B. Ufać sobie i troszczyć się o siebie nawzajem.

C. Regularnie ze sobą rozmawiać.

Zgodnie z informacją zawartą w kluczu rozwiązań znajdującym się na końcu omawianego Zeszytu ćwiczeń, w obu zadaniach prawidłowe są wszystkie odpowiedzi, a więc A, B i C. W zadaniach tych powtórzono zadania z podręcznika, zaznaczone do zapamiętania, nieznacznie tylko je modyfikując. W gruncie rzeczy więc sprawdzeniu podlega to, czy uczniowie rozpoznają fragmenty podręcznika i czy potrafią prawidłowo zaznaczać odpowiedzi w Zeszycie ćwiczeń. Z testowaniem kompetencji moralno-etycznej nie ma to nic wspólnego, gdyż w obu pytaniach należy zaznaczyć wszystkie odpowiedzi jako prawidłowe. 
Pracując nad zmodyfikowaniem powyższych zadań i przekształceniem ich w zadania nadające się do zastosowania w badaniu ETiK-International, ponownie dążyliśmy do podniesienia poziomu złożoności wyjściowej sytuacji problemowej, a przez to do poszerzenia przestrzeni, w której należało rozważać tę sytuację i szukać dla niej rozwiązania. Nie bez znaczenia było przy tym przekształcenie pytania w taki sposób, żeby wyeksponować w nim moment aktywej refleksji, a nie tylko pasywnej reprodukcji wiedzy.

Przy konstruowaniu nowych zadań zwrócił naszą uwagę fakt, że w zadaniach z Zeszytu ćwiczeń w ogóle nie poddawano pod ocenę konkurujących ze sobą opcji postępowania. W związku z tym postanowiliśmy na tej właśnie obserwacji oprzeć naszą pracę. Żeby jednak nie dać się kierować europejskim respective niemieckim wyobrażeniom moralnym, do poszukiwania odpowiednich przykładów wykorzystaliśmy chińskie podręczniki. Przykładowo, w podręczniku do bezustannie przywoływanego tu przedmiotu „Myślenie i cnota” postuluje się od uczniów i uczennic, żeby ewentualną wzajemną skłonność „ukryli głęboko w sercu na dnie” (Myślenie $i$ cnota 2014a, s. 11). Na uzasadnienie tego postulatu autorzy podręcznika podają, że taka skłonność, jeżeli straci się nad nią kontrolę i okazuje się ją publicznie, może mieć negatywny wpływ na osiągnięcia szkolne i całe dalsze życie. Te wyjaśnienia młodzi ludzie mogą odczytywać jako zachętę do tego, żeby takie i tym podobne stany rzeczy i uczucia powierzać raczej swoim pamiętnikom. Gdyby w chińskim zeszycie ćwiczeń wykorzystano to jako motyw przewodni do zadań odnoszących się do zakresu tematycznego „Życie w rodzinie”, z pewnością pojawiłyby się w nim opisy sytuacji, w których przykładowo córka nie chce przed rodzicami ujawnić swojej sympatii do kogoś i opisuje to w pamiętniku. Matka, która nie powinna właściwie zaglądać do tego pamiętnika, potajemnie jednak go czyta i dowiaduje się o przyczynie smutku i boleści córki. Dzięki temu może teraz odpowiednio zintepretować jej zachowanie.

Nowe zadanie, które przygotowaliśmy na podstawie powyższych rozważań, ma następującą postać:

Yabin (15 lat) zakochała się swoim koledze ze szkoły Lee i na podstawie pewnych oznak może sądzić, że jej uczucie jest przez niego odwzajemniane. Uczennica nikomu o tym nie mówi, ale swoją tajemnicę ujawnia w pamiętniku, który prowadzi. Matka Yabin zauważa, że córka stała się cicha i wycofana, i martwi się o nią. Najpierw pyta wprost córkę o powód jej nietypowego zachowania. Następnie wypytuje koleżanki z klasy, a potem prosi również wychowawcę o rozmowę w tej sprawie. Nie mogąc dowiedzieć się, co jest przyczyną zachowania Yabin, postanawia potajemnie zajrzeć do jej pamiętnika.

A. Podaj w kilku zdaniach argumenty, które z moralno-etycznego punktu widzenia przemawiają za czynem matki (maks. 30 słów): 
B. Podaj w kilku zdaniach argumenty, które z moralno-etycznego punktu widzenia przemawiają przeciw czynowi matki (maks. 30 słów):

C. Jak mogłaby przebiegać rozmowa Yabin i jej matki na temat zainstniałej sytuacji i jak mogłoby wyglądać rozwiązanie, w którego realizację zostałby wlączony Lee, przyjaciel Yabin? (maks. 30 słów)

Nowe zadanie nie jest bynajmniej sprzeczne z chińskimi normami moralnymi ani nie retuszuje ich według zachodnich standardów - w tym przypadku niemieckich. Uczniowie mają za zadanie, po pierwsze, przedstawić argumenty, które ich zdaniem przemawiają za respective przeciw postępowaniu matki, po drugie zaś naszkicować przebieg rozmowy, w której wywołany przez obie strony problem może zostać rozwiązany w odpowiedni sposób.

Według naszych przypuszczeń chińscy uczestnicy badania ETiK-International będą w stanie sprostać wyzwaniu, żeby odpowiadając na powyższe pytania, uwzględnić postawę szacunku, troski i ufności, która jest nakazana nie tylko Yanbin w stosunku do matki, lecz również vice versa - matki wobec córki. Ponadto w propozycji rozwiązania problemu będą oni potrafili uwzględnić „sekretnego” przyjaciela Yanbin, Lee, który ma również swój udział w sprawie.

\section{Obszar tematyczny „Pomoc wzajemna - między legalnością i moralnością”}

Odnośnie do powyższego obszaru tematycznego wybrano z Zeszytu ćwiczeń do przedmiotu „Myślenie i cnota” (2013, s. 24) następujące zadanie:

Tylko jedna podanych poniżej odpowiedzi jest prawidłowa!

Prawo i moralność odnoszą się do siebie nawzajem tak, że prawo...

A. Uzgadnia się z poglądami prezentowanymi w mass mediach.

B. Jest gwarantowane przez władzę państwową.

C. Określa podstawowe prawa obywateli.

D. Odnosi się tylko do przestępców. 
W Zeszycie ćwiczeń, z którego zapożyczono to zadanie, podano, że prawidłowa jest tylko odpowiedź B. Najprawdopodobniej wynika to stąd, że zreproduktowano w niej centralną myśl zawartą w odpowiedniej sekcji podręcznika. Tak więc zadaniem uczniów nie jest bynajmniej zastanawianie się nad jakimś problemem i rozważenie go, lecz bezwiedne zaznaczenie jedynie słusznej odpowiedzi. Żeby jednak się dowiedzieć, czy różnica między moralnością i prawem jest im w ogóle znana, należało przekształcić to zadanie, zachowując oczywiście relację z kontekstem podręcznika, z którego ono pochodzi.

Podobnie jak poprzednio nasze postępowanie wygłądało tak, że przejęliśmy po prostu rozróżnienie zachowań obowiązujących w Europie respective w Niemczech, lecz postanowiliśmy opracować samodzielnie taką sytuację problemową, w której uwidocznią się różnice między chińskim a zachodnim systemem prawnym. W przeciwieństwie do nowoczesnych państw cywilizacji euro-amerykańskiej, w obowiązującym w Chinach systemie prawnym nie istnieje przestępstwo polegające na zawinionym nieudzieleniu pomocy. Niemniej jednak obowiązek okazania bliźniemu pomocy jest mocno zakorzeniony w chińskich zwyczajach i moralności. Ta konstatacja naprowadziła nas na pomysł, żeby powyższe zadanie z zeszytu ćwiczeń przeformułować na takie, w którym respondenci będą mogli wypowiedzieć się na temat relacji między prawem a moralnością na podstawie różnicy występującej w Chinach między przepisami prawnymi a obyczajami. To, jak uczniowie poradzą sobie $\mathrm{z}$ tym problemem, miało dostarczyć nam wiedzy o ich umiejętności interpretowania nakazów moralnych i odróżniania norm kulturowych od prawnych.

Nowe, przeformułowane zadanie wygląda tak:

W dyskusjach etycznych i prawnych często istnieje różnica między nakazami moralnymi i prawnymi. Przez pojęcie legalności rozumie się przestrzeganie prawa państwowego, natomiast moralność oznacza spełnianie obowiązków etycznych, którym człowiek podlega, niezależnie od stanu prawnego w danym państwie. Wskazania prawne i moralne mogą być zgodne, pozostawać neutralne wobec siebie lub kolidować ze sobą.

W Chinach, inaczej niż w Niemczech, nie ma prawnego zobowiązania do udzielenia osobie znajdującej się w niebezpieczeństwie pomocy. Jeżeli ktoś tego nie zrobi w Chinach, nie zostanie ukarany.

Odnosząc się do sytuacji prawnej w Chinach i w Niemczech, oceń przedstawiony poniżej przykład najpierw z punktu widzenia prawa, a następnie moralności. Sprawdź, czy zachodzi różnica w postępowaniu między Chinami a Niemcami.

Przykład: 
Ktoś umiejący pływać właśnie uprawia jogging, biegnąc wzdłuż jeziora w Szanghaju. Nagle spostrzega, że dziecko znajdujące się nad jeziorem ze swoją matką wpadło do wody i się topi. Matka woła o pomoc, ponieważ nie umie pływać. Sportsmen biegnie jednak dalej.

A. Oceń powyższy przykład z punktu widzenia prawa (maks. 30 słów).

B. Oceń powyższy przykład z punktu widzenia moralności (maks. 30 słów).

Zaproponowana powyżej nowa wersja zadania odnosi się do sytuacji, którą można interpretować nie tylko z perspektywy dwóch odmiennych, a nawet skrajnie przeciwstawnych systemów prawnych, lecz dodatkowo jeszcze z punktu widzenia moralności, która w tej sytuacji okazuje się być identyczna w Chinach i Niemczech, mimo różnic kulturowych. Z punktu widzenia prawa ocena przedstawionego przykładu zależy od znajomości przepisów normujących sytuację prawną związaną z zaniechaniem udzielenia pomocy respective nienormujących takiej sytuacji. Jeżeli jednak chodzi o moralno-etyczną stronę zdarzenia, które opisano w przykładzie, działanie sportsmena podlega ocenie ze względu na inne jeszcze kryteria niż te sformułowane w postaci przepisów prawa.

Według naszych przypuszczeń chińscy uczniowie potrafią dostrzec różnicę między stanem prawnym a sytuacją moralną i odpowiednio do tego ocenić zdarzenie opisane w przykładzie z perspektyw prawnej i moralno-etycznej. Jakich argumentów użyli, żeby dać wyraz swoim przekonaniom, o tym dowiemy się po zakończeniu ewaluacji wyników pierwszego badania pilotażowego.

\section{Wstępne wyniki}

Jak wspomniano powyżej, nie zostały jeszcze zakończone analizy statystyczne danych uzyskanych w trakcie przeprowadzonego w maju 2015 roku w Szanghaju pierwszego badania pilotażowego. $Z$ napięciem oczekujemy nie tylko wyników uzyskanych przez chińskich uczniów w zadaniach testowych, lecz przede wszystkim informacji zwrotnych o ich odpowiedziach na otwarte pytania. Te ostatnie posłużą nam do ustalenia kryteriów, jakimi będziemy się kierować przy ocenie wartości odpowiedzi podczas badania zasadniczego. Praca nad tymi kryteriami już teraz da nam w pewnym sensie odpowiedź na pytanie, czy pytania testowe zawarte w TKM-EP, włącznie z tymi opracowanymi na podstawie zeszytów 
ćwiczeń, nie okazały się zbyt złożone i niemożliwe do rozwiązania przez chińskich respondentów.

Poniżej przedstawiamy odpowiedzi uzyskane na zaprezentowane pod koniec poprzedniej części zadanie dotyczące obszaru tematycznego „Pomoc wzajemna - między legalnością i moralnością”. Jak nadmieniono w poprzednim akapicie, odpowiedzi takie jak ta zostaną wykorzystane do przygotowania klucza, według którego w badaniu zasadniczym będą oceniane wypowiedzi uczniów z Chin na otwarte pytania.

Nasza praca nad analizą zebranych opinii na temat wspomnianego zadania przebiegała następująco. Najpierw zestawiono ze sobą wszystkie odpowiedzi A i B (było ich około 50), podzielono je na trzy grupy i przetłumaczono na język niemiecki. Odnośnie do podziału na grupy trzeba wyjaśnić, że do pierwszej grupy zakwalifikowano wypowiedzi, których autorzy wyraźnie wyprowadzają ocenę etyczno-moralną zachowania osoby uprawiającej jogging ze stanu prawnego. W drugiej grupie znalazły się opinie, których autorzy rozróżniają między prawnym (normatywnym) statusem sytuacji, a tym, co powinien zrobić sportsmen, jeżeli będzie się kierował oceną moralno-etyczną. Zgromadzone w tej grupie wypowiedzi świadczą naszym zdaniem o tym, że zakwalifikowani do niej uczniowie nie redukują moralności do przepisów prawa. Na trzecią grupę złożyły się wypowiedzi nastolatków, którzy nie tylko potrafili odseparować prawną ocenę sytuacji od moralno-etycznej, lecz również na tej podstawie wskazywali kierunek dalszego rozwoju chińskiego systemu prawnego.

Poniżej przedstawimy przykłady zebranych opinii w odniesieniu do każdej $\mathrm{z}$ trzech grup, na które je podzieliliśmy. Następnie zostaną wysnute wstępne reguły, które posłużą członkom szanghajskiego zespołu realizującego badanie ETiK-International do oceny wartości odpowiedzi udzielonych na otwarte pytania w omawianym obszarze, tj: „Pomoc wzajemna - między legalnością i moralnością”.

Grupa I - brak rozróżnienia między oceną prawną i etyczno-moralną (przykład wypowiedzi):

1) A (uzasadnienie prawne): „Ten człowiek złamał prawo”.

2) B (zasadnienie moralno-etyczne): „Dziecko nie należy do tego mężczyzny”.

Grupa II - rozróżnianie między oceną prawną i etyczno-moralną (przykłady wypowiedzi):

1) A (uzasadnienie prawne): „Sytuacja, w której znalazła się matka i dziecko, od strony prawnej nie dotyczy mężczyzny. Dlatego nie ma potrzeby, żeby czuł się za niego odpowiedzialny".

2) B (zasadnienie moralno-etyczne): „Postępowenie mężczyzny świadczy o rozkładzie moralności i upadku obyczajów”.

3) A (uzasadnienie prawne): „Mężczyzna jest niewinny. Matka powinna lepiej chronić swoje dziecko".

4) B (zasadnienie moralno-etyczne): „Ten mężczyzna nie jest człowiekiem. Nie ratuje małego dziecka”. 
Grupa III - rozróżnianie między oceną prawną i etyczno-moralną, i refleksyjne wytłumaczenie sytuacji (przykłady wypowiedzi):

1) A (uzasadnienie prawne): „Mężczyzna swoim postępowaniem nie złamał prawa; chodzi tu o pewien dezyderat wobec chińskiego prawodawstwa”.

2) B (zasadnienie moralno-etyczne): „Postępowanie mężczyzny świadczy o rozkładzie moralności. Nie okazał elementarnego współczucia”.

3) A (uzasadnienie prawne): „Mimo że obecnie w Chinach nieudzielenie pomocy nie jest złamaniem prawa, to jednak Chiny powinny wprowadzić taki przepis”.

4) B (zasadnienie moralno-etyczne): „Zachowanie mężczyzny jest niemoralne. Nie można nie udzielić pomocy w sytuacji zagrożenia życia”.

Charakterystycznym rysem odpowiedzi zaliczonych do trzeciej grupy było to, że nie znać w nich było prób zaprowadzania jakiejkolwiek hierarchii między ocenami moralnymi a prawnymi (lepsze - gorsze, wyższe - niższe), lecz formułujący te odpowiedzi uczniowie byli skupieni na relacjach łączących oba rodzaje argumentowania i expressis verbis je przemyśliwali. Można byłoby zaryzykować twierdzenie, że wypowiedzi niektórych uczniów współgrały ze słynną sentencją łacińską, przekazaną potomności przez Ambrozjusza Makrobiusza, a mianowicie: Leges bonae ex malis moribus procreantur [co po polsku znaczy: „Złe obyczaje dają początek dobrym prawom" - dop. D.S.]. Jak to było wyraźnie widać w jedym z powyższych przykładów, niektórzy z uczniów rozpatrywali konieczność wprowadzenia również w Chinach kary za nieudzielenie pomocy w sytuacji zagrożenia życia, skoro tradycyjny chiński obyczaj niesienia sobie nawzajem pomocy jest przez wielu lekceważony.

$\mathrm{W}$ instrukcji, która powstanie po wnikliwym przeanalizowaniu wszystkich odpowiedzi udzielonych na otwarte pytania, powinny znaleźć się jednoznaczne dyspozycje, jak należy ocenić każdą ewentualną wypowiedź. Na podstawie przeprowadzonej powyżej eksploracji można wysnuć następujące dyrektywy odnośnie do tej oceny:

A. Perspektywa prawna:

1) full credit (2 punkty) - gdy respondent $z$ podanych czterech argumentów (a-d) przytoczy co najmniej dwa;

2) partial credit (1 punkt) - gdy respondent $z$ podanych czterech argumentów (a-d) przytoczy tylko jeden;

3) no credit (żadnego punktu) - gdy respondent z podanych czterech argumentów (a-d) nie przytoczy żadnego.

Argumenty:

1) odwołanie się do i podkreślenie podstawy prawnej;

2) wskazanie na to, że podstawa prawna może być różna w różnych krajach;

3) wskazanie, że podstawa prawna może się zmieniać;

4) podjęcie problemu nieudzielania pomocy. 
Przykłady oceniania:

1) full credit

a) „W Chinach nie ma prawa, które wymierza karę za nieudzielenie pomocy w sytuacji zagrożenia życia. Dlatego mężczyzna nie łamie prawa chińskiego. Ale gdyby mieszkał w Niemczech, zostałby za to ukarany" (a, b, c).

b) „Mężczyzna swoim postępowaniem nie złamał prawa; chodzi tu o pewien dezyderat wobec chińskiego prawodawstwa" $(a, c)$.

2) partial credit

a) „Mężczyzna nie wykroczył przeciwko prawu. Jego postępowanie jest zupełnie normalne" (a).

b) „Mężczyzna nie spowodował bezpośrednio śmierci dziecka” (d).

3) no credit

a) „Gdyby był Niemcem, powinien zostać ukarany. Ponieważ jest Chińczykiem, nie może być ukarany".

b) „Mężczyzna postąpił właściwie, bo nie musi płacić rachunku za cudze błędy”.

B. Perspektywa moralno-etyczna:

1) full credit (2 punkty) - gdy respondent poda oba poniższe argumenty;

2) partial credit (1 punkt) - gdy respondent poda jeden z poniższych argumentów;

3) no credit (żadnego punktu) - gdy respondent nie poda żadnego poniższych argumentów, a ocena zostanie uzależniona od jego widzimisię.

Argumenty:

1) wyraźne uzasadnienie niemoralnego charakteru działania mężczyzny;

2) wskazanie na sumienie.

Przykłady oceniania:

1) full credit

a) „Nieudzielenie pomocy w sytuacji zagrożenia życia jest nieetyczne. Ktoś, kto tak postępuje, nie okazuje życzliwości ani chęci pomocy drugiemu” (a,b).

b) „Mężczyzna powinien ratować życie dziecka, gdyż umie pływać. Nic nie jest ważniejsze od życia. Widział, jak dziecko się topi. Powinien mieć wyrzuty sumienia" $(a, b)$.

2) partial credit

a) „Zaniechanie pomocy w sytuacji zagrożenia życia jest niemoralne” (a).

b) „Mężczyzna powinien odczuwać wyrzuty sumienia” (b).

3) no credit

a) „Mężczyzna ma prawo wybrać, czy ratować dziecko, czy nie”.

b) „Mężczyzna postąpił dobrze; wie, jak się chronić”. 


\section{Plany na przyszłość}

Do pytań, które znajdą rozstrzygnięcie dopiero po przeprowadzeniu w Szanghaju badania zasadniczego, planowanego na rok szkolny 2016/2017, należą:

1) jakie podobieństwa i różnice zachodzą między wynikami uzyskanymi przez uczniów z Chin a tymi, które osiągnęli uczniowie w Niemczech i innych krajach europejskich?;

2) czy i jeżeli tak, to jakie oznaki dowodzą, że w Chinach mamy do czynienia z pewnego rodzaju transformacyjnym uniwersalizmem powtarzania, którego punktem wyjścia jest chińska tradycja?;

3) jakie różnice kulturowe ogrywają główną rolę w kreowaniu wspomnianego powyżej transformacyjnego uniwersalizmu powtarzania w Chinach?

Dopiero wóczas, gdy to zostanie wyjaśnione, będzie można również poszukiwać odpowiedzi na dalsze pytania, które nasuwają się wprost automatycznie, a mianowicie: czy potwierdzą się uzyskane w badaniach przeprowadzonych w Niemczech respective Europie koncepcje: struktura kompetencji moralno-etycznej złożona z trzech kompetencji cząstkowych - podstawowej wiedzy moralno-etycznej (PWM-E), kompetencji sądzenie moralno-etycznego (KSM-E) i kompetencji projektowania działania moralno-etycznego (KPDM-E) wraz z odpowiednimi poziomami oczekiwań, czy też nie. Jeżeli nie, to jakich modyfikacji będą wymagać wymienione koncepcje. Nie mniej ekscytujące jest pytanie: jak uczniowie i uczennice z Europy rozwiążą nowe zadania testowe przygotowane dla Chin i jak chińscy respondenci si do niego ustosunkują? Być może dzięki realizacji badania ETiK-International opracowane w Berlinie narzędzie badawcze - TKM-EP będzie musiało ulec modyfikacji? W którym kierunku pójdą zmiany? Katalog pytań jest niemalże nieskończony. Miejmy nadzieję, że wkrótce poznamy pierwsze odpowiedzi.

Przetłumaczył z języka niemieckiego Dariusz Stępkowski

\section{Bibliografia}

Benner D. (2006), Pedagogika ogólna, tłum. chińskie Xu Binyan. Shanghai.

Benner D., Peng Z., von Oettingen A., Stepkowski D. (2015). Bildung - Moral Demokratie. Theorien und Konzepte moralischer Erziehung und Bildung und ihre Beziehungen zu Ethik und Politik. Paderborn-München-Wien-Zürich: Schöningh.

Brüning B. (2006) (red.). Gemeinsam erwachsen werden. Leipzig: Militzke.

Brüning B. (2008). Eine Welt für alle. Leipzig: Militzke.

Myślenie i cnota. Podręcznik (2014a). T. 7a (pierwszy semestr klasy 7). Szanghaj: Educational Science Publishing House.

Myślenie i cnota. Podręcznik (2014b). T. 7b (drugi semestr klasy 7). Szanghaj: Educational Science Publishing House. 
Peng Zh., Peng T. (2016). Die Modernisierung der chinesischen moralischen Erziehung und die historische Verortung des Projekts ETiK-Shanghai-international.?

Program nauczania przedmiotów: Myślenie i cnota oraz Myślenie i polityka (2004). Szanghaj: Educational Science Publishing House.

Walzer M. (1996). Lokale Kritik - globale Standards. Zwei Formen moralischer Auseinandersetzung. Hamburg: Rotbuch Verlag.

Wymagania programowe dla przedmiotów: Myślenie i chota oraz Myślenie i polityka (2010). Szanghaj: Educational Science Publishing House.

Zeszyt ćwiczeń. Myślenie i cnota (2008). Tom 6a (pierwszy semestr klasy 6). Szanghaj: Educational Science Publishing House.

Zeszyt ćwiczeń. Myślenie i cnota (2010). Szanghaj: Educational Science Publishing House.

Zeszyt ćwiczeń. Myślenie i cnota (2013). Pekin: Capital Normal University Press.

Zeszyt ćwiczeń. Myślenie i cnota (2014). Tom $7 \mathrm{~b}$ (drugi semestr klasy 7), Szanghaj: Educational Science Publishing House.

\title{
ETIK-INTERNATIONAL STUDY IN SHANGHAI. RESEARCH PROJECT AND REPORT ON ADAPTING TESTS TO CHINESE SOCIAL AND CULTURAL CONDITIONS
}

\begin{abstract}
A team of scientists from Shanghai set about preparing and conducting ETiKInternational study in China. This article describes the formation of the team and their preparations for conducting the project carried out so far. The paper also contains an extensive description of the works on modifying the tests and adapting them to the Chinese social and cultural context.
\end{abstract}

Keywords: ETiK-International study, tests, moral and ethical skills, universalism of repetition.

Zhengmei Peng - doktor pedagogiki, profesor East China Normal University w Szanghaju (Chiny), kierownik Katedry Teorii Kształcenia. Publikacje książkowe: razem z D. Benner, A. von Oettingen, D. Stępkowski - Bildung - Moral - Demokratie (2015). Adres mejlowy: zmpeng@kcx.ecnu.edu.cn.

Tao Peng - magister pedagogiki, uczestnik studiów doktoranckich w Humboldt Universität w Berlinie (Niemcy). Adres mejlowy: Ludwig47@163.com. 